\title{
Evaluation of human leukocyte antigen class I and Il antigens in Helicobacter pylori-positive pediatric patients with active gastritis and duodenal ulcer
}

\author{
Sevim GÖNEN', Sinan SARI ${ }^{2}$, Yaşar KANDUR ${ }^{3}$, Buket DALGIÇ² and Oğuz SÖYLEMEZOĞLU3
}

Received 12/7/2017 Accepted 30/8/2017

\begin{abstract}
Background - As being the first bacteria determined to be carcinogenic, Helicobacter pylori (H. pylori) is a pathogen localized in the stomach in more than half of the world population. Some earlier studies have found a relation between tissue histocompatibility antigens and gastric cancers depending on the regions. Objective - The present study aimed to determine the distribution of human leukocyte antigen (HLA) class I and class II antigens in $H$. pylori-positive pediatric patients with active gastritis and duodenal ulcer, excluding cancer cases, in our center. Methods - The study included 40 patients diagnosed with $H$. pylori-positive active gastritis and duodenal ulcer and 100 controls consisting of healthy donor candidates. The HLA class I and class II antigens were studied in the isolated DNA samples using the polymerase chain reaction sequence-specific oligonucleotide probes. Results - The frequency of HLA-B*51 antigen was significantly higher in the patient group than in the control group ( $40 \%$ vs $17 \%$; $P=0.003)$. There was no difference between the two groups in terms of the frequencies of HLA-A, HLA-C, HLA-DR, and HLA-DQ antigens. Conclusion - It was determined that HLA-B*51 plays a critical role in $H$. pylori infection.
\end{abstract}

HEADINGS - Duodenal ulcer. Gastritis. Helicobacter pylori. HLA Antigens. Child.

\section{INTRODUCTION}

Helicobacter pylori (H. pylori) is spiral or comma-shaped Gram-negative bacilli that exhibits host and tissue tropism and can be colonized in the gastric antrum and cardia and also in all gastric regions including corpus and duodenum, where gastric cell metaplasia is observed, in humans and in some primates ${ }^{(4,8)}$.

The human leukocyte antigens (HLAs), which are expressed on the human cell surface, regulate the immune response ${ }^{(9,13)}$. The studies continuing for years on the relation between HLA and diseases are rapidly increasing today. For this reason, the importance of conducting HLA studies in different populations for the same disease is obvious. There are numerous publications demonstrating the relation between HLA antigens and diseases. Such type of studies are conducted to determine the risks and preventive factors for the diseases, to plan treatment, to understand whether they are genetically transmitted, and consequently to reach a molecular pathogenesis ${ }^{(1)}$. In order to enlighten the pathogenesis of $H$. pylori infections, there are many studies using molecular methods and many gene regions determined as targets. Recent studies have supported the hypothesis that genetic predisposition associated with human leukocyte antigen (HLA) genes have a role in the development of gastric cancer. In $\mathrm{H}$. pylori-positive gastric cancers, studies especially conducted on class II HLA-DRB1* and HLADQB1* antigens attract attention ${ }^{(5,7)}$. To our knowledge, there are no studies on tissue groups in $H$. pylori-positive pediatric patients with active gastritis and duodenal ulcer in Turkish population. The present study aimed to investigate tissue groups in H. pyloripositive pediatric patients with active gastritis and duodenal ulcer in Turkish population as compared to a control group. Moreover, class I antigens were also investigated since data on the literature mainly include studies on class II antigens.

\section{METHODS}

The present study included 40 pediatric patients (19 boys and 21 girls; mean age: 9.5 years) who had active gastritis and duodenal ulcer and were admitted to the Gastroenterology Department of Medical Faculty of Gazi University between 2014 and 2015. The control group consisted of 100 healthy bone marrow candidate donors (45 males and 55 females, mean age: 12 years) who were admitted to the Tissue Typing Laboratory of our hospital. The DNA samples of the patients and controls were isolated from the blood samples containing ethylenediaminetetraacetic acid (EDTA) using the BioRobot EZ1 system (Qiagen GmbH, Hilden, Germany). The HLA class I and class II antigens were studied in the isolated DNA samples using the polymerase chain reaction (PCR) sequence-specific oligonucleotide probes (PCR-SSO, Luminex; Tepnel Lifecodes, Stanford, CA, USA).

DNA samples, on which DNA typing would be performed, were prepared for amplification using HLA-A, -B, -C, -DQ, -DR kits (Tepnel Lifecodes Corp., Bend, Oregon, USA). For each HLA typing, MasterMix, distilled water, and Taq polymerase were prepared and put into 8 PCR tubes (Thermo Fisher Scientific ${ }^{\mathrm{TM}}$, Massachusetts, USA) and DNA was then added. Thereafter, amplification was performed using Corbett Palm-Cycler (Corbett Life Science, Austria) using the following PCR cycles: 1 cycle at $95^{\circ} \mathrm{C}$ for $5 \mathrm{~min}$ followed by $30 \mathrm{~s}$ at $95^{\circ} \mathrm{C}$, and $45 \mathrm{~s}$ at $60^{\circ} \mathrm{C} ; 8$ cycles at $72^{\circ} \mathrm{C}$ for 45

Declared conflict of interest of all authors: none

Disclosure of funding: no funding received

${ }^{1}$ Laboratory of Tissue Typing and Pediatric Nephrology, Gazi University Faculty of Medicine, Ankara, Turkey; ${ }^{2}$ Department of Pediatric Gastroenterology, Gazi University Faculty of Medicine, Ankara, Turkey; ${ }^{3}$ Department of Pediatric Nephrology, Gazi University Faculty of Medicine, Ankara, Turkey.

Correspondence: Sevim Gönen. Gazi University Faculty of Medicine, Laboratory of Tissue Typing and Pediatric Nephrology Beşevler, Ankara, Turkey. E-mail: sevgonen@gmail.com 
s followed by $30 \mathrm{~s}$ at $95^{\circ} \mathrm{C}, 45 \mathrm{~s}$ at $63^{\circ} \mathrm{C} ; 32$ cycles at $72^{\circ} \mathrm{C}$ for $45 \mathrm{~s}$ followed by 1 cycle at $72^{\circ} \mathrm{C}$ for $15 \mathrm{~min}$; and finally 1 cycle at $4^{\circ} \mathrm{C}$ for $5 \mathrm{~min}$. After the amplification process, the samples could be stored at $+2-+8^{\circ} \mathrm{C}$ for $24 \mathrm{~h}$ until analysis. During the analysis, 5 $\mathrm{mL}$ of amplified products was added to the Costar plates. It was then heated at $55^{\circ} \mathrm{C}$ for 7 min using a sonication device (Ultrasonic cleaner, Branson 200, Branson Soest, Netherlands) and then left for $15 \mathrm{~s}$. After the beads from the HLA-A, -B, -C, -DQ and -DR kits were vortexed (V-1 plus, Personal Vortex, Biosan, Riga, Latvia), $15 \mathrm{~mL}$ of these beads were added to $5 \mathrm{~mL}$ of DNA samples in the Costar plates. Thereafter, the Costar plates were placed into the Corbett Palm-Cycler device (Corbett Life Science, Austria), hybridization process was started $\left(5 \mathrm{~min}\right.$ at $97^{\circ} \mathrm{C}, 30 \mathrm{~min}$ at $47^{\circ} \mathrm{C}$, $10 \mathrm{~min}$ at $56^{\circ} \mathrm{C}, 10 \mathrm{~min}$ at $56^{\circ} \mathrm{C}$ ). Near the end of the hybridization process, a mixture of dilution solution, which was obtained from the kits and prepared for each costar plate well, and streptavidin was prepared; after completion of the hybridization process, a 170 $\mu \mathrm{L}$ of this mixture was added into the wells. The Costar plate was then placed in the Luminex device (Tepnel Lifecodes, Stanford, CA, USA) and the evaluation was performed automatically by the system.

The present study was approved by the Local Ethics Committee and conducted in accordance with the Declaration of Helsinki. Informed consents were obtained from the parents/legal guardians of the patients and from the controls.

\section{Statistical analysis}

All results were presented as the mean \pm standard deviation. Hardy Weinberg equilibrium was tested by grouping the allele frequencies which were less than 5. Levels of significance were determined using contingency tables by either the Chi-squared test or Fisher's exact analysis. Statistical significance was defined as $P \leq 0.05$. Statistical analysis was performed by using the Statistical Package for the Social Sciences (version 12.0; SPSS, Inc., Chicago, IL, USA).

\section{RESULTS}

The distributions of HLA class I and class II antigens in the $H$. pylori-positive patients $(\mathrm{n}=40)$ with active gastritis and duodenal ulcer and in the controls $(n=100)$ are demonstrated in Table 1 and Table 2, respectively. When the frequency of HLA class I antigens were examined, HLA-A*02 and HLA-Cw*07 were detected in $50 \%$

TABLE 1. Distribution of human leukocyte antigen (HLA) class I antigens in the H.pylori-positive patients and controls

\begin{tabular}{lccccc}
\hline $\begin{array}{l}\text { HLA class I } \\
\text { antigens }\end{array}$ & \multicolumn{2}{c}{$\begin{array}{c}\text { Patients group } \\
(\mathrm{n}=40)\end{array}$} & \multicolumn{2}{c}{$\begin{array}{c}\text { Control group } \\
(\mathrm{n}=100)\end{array}$} & $\boldsymbol{P}$ \\
\hline HLA-A*02 & $\mathrm{n}$ & $\%$ & $\mathrm{n}$ & $\%$ & \\
HLA-A*24 & 20 & 50 & 36 & 36.0 & 0.126 \\
HLA-B*51 & 17 & 42.5 & 30 & 30.0 & 0.157 \\
HLA-B*35 & 16 & 40 & 17 & 17.0 & 0.003 \\
HLA-Cw*07 & 19 & 27.5 & 29 & 29.0 & 0.862 \\
HLA-Cw*12 & 10 & 25.0 & 29 & 29.0 & 0.631 \\
\hline
\end{tabular}

HLA: human leukocyte antigen.
TABLE 2. Distribution of human leukocyte antigen (HLA) class II antigens in the $H$. pylori-positive patients and controls

\begin{tabular}{lccccc}
\hline $\begin{array}{l}\text { HLA class II } \\
\text { antigens }\end{array}$ & $\begin{array}{c}\text { Patients group } \\
(\mathrm{n}=40)\end{array}$ & \multicolumn{2}{c}{$\begin{array}{c}\text { Control group } \\
(\mathrm{n}=100)\end{array}$} & $\boldsymbol{P}$ \\
\hline HLA-DRB1*04 & $\mathbf{n}$ & $\%$ & $\mathrm{n}$ & $\%$ & \\
HLA-DRB1*13 & 13 & 32.5 & 19 & 19.0 & 0.085 \\
HLA-DRB1*11 & 11 & 27.5 & 34 & 34.0 & 0.458 \\
HLA-DQB1*03 & 35 & 87.5 & 83 & 83.0 & 0.507 \\
HLA-DQB1*05 & 14 & 35.0 & 29 & 29.0 & 0.488 \\
HLA-DQB1*02 & 10 & 25.0 & 28 & 28.0 & 0.718 \\
\hline
\end{tabular}

HLA: human leukocyte antigen.

and $47.50 \%$ of the patients, respectively; however, there was no significant difference as compared with the control group. Among the HLA class I antigens, HLA-B*51 was determined in $40 \%$ of the patients and in $17 \%$ of the controls. The difference was found to be significant $(P=0.003)$. The frequency of HLA class II antigens was similar in the patient and control groups. No other significant differences were determined.

\section{DISCUSSION}

Ulcer disease has been found two times more prevalent in the children of families with peptic ulcer as compared with the general population. In addition, it has been suggested that blood type $\mathrm{O}$ is dominant among the cases with duodenal or gastric ulcer. With regard to the host factor, there are studies demonstrating increased expressions of HLA-DR, HLA-DQB 1 *and HLA-DQA1* in cases with $H$. pylori infection as compared to those without ${ }^{(2,3)}$. The aim of performing numerous studies on the relation between HLA antigens and diseases is to determine the risks of and preventive factors for diseases and to plan the treatment. For this reason, it is obvious that performing HLA studies in different populations for the same disease is important ${ }^{(15)}$.

In the present study, the most common HLA class I antigens were found as HLA-A*02, HLA-A*24, HLA-B*35, HLA-B*51, HLA-Cw*07, and HLA-Cw*12. The most common HLA class II antigens were found as HLA-DRB1*04, HLA-DRB1*11, HLADRB1*13, HLA-DQB1*02, HLA-DQB1*03, and HLA-DQB1*05. Particularly, HLA-B*51 was found to be significantly more frequent in the patients with active gastritis and duodenal ulcer. No significant difference was found between the patient and control groups in terms of the other tissue group antigens. In the present study, the frequency of HLA-B*51 antigen was $40 \%$ in the patient group and significantly higher than in the control group $(17 \% ; P<0.003)$. The number of studies on HLA-B* antigens are limited.

To the best of our knowledge, there is only one study investigating the HLA class I and II antigens in the H. pylori-positive adult patients with gastric cancer, in which the distributions of HLA-DRB1*01 and HLA-Cw*03 were found to be significantly different between patients and controls ${ }^{(6)}$. Many studies related to HLA antigens in the literature have focused on screening of class II antigens especially in cancer cases ${ }^{(12,14)}$. Our study was the 
first to simultaneously investigate the HLA class I and II antigens in $H$. pylori-positive pediatric patients with active gastritis and duodenal ulcer and the relationship with the HLA-B*51 antigen was demonstrated. However, the present study has a small sample size; thus, further studies with larger sample sizes are required in the long term.

In recent years, various studies have reported a relation between HLA class II antigens and $H$. pylori gastritis ${ }^{(10,11)}$. Different outcomes from different populations have suggested that each population needs to identify its own risky HLA group.

The results of the present study and other studies have suggested that broad polymorphism of HLA may have an important role in gastric diseases, particularly in the control of inflammatory and immune reactions. Both population-based and experimental approaches are required to enlighten the mechanism of HLA and the effects of immunogenic factors in gastric diseases and also the interaction between immunogenetic and environmental factors in the development of gastric disease.

\section{CONCLUSION}

The relation of HLA with $H$. pylori is important. It is observed that some HLA alleles can bind their own peptides and that they display T-cell reactions spontaneously to the antigens due to amino acid motifs in the critical regions of HLA molecules. Co-existence of $H$. pylori and HLA-B*51 suggests a genetic component in the pathogenesis of $H$. pylori infection. Each ethnic population is recommended to conduct studies to identify their own HLA antigen and its relation with this disease. Finally, we are in the opinion that further comprehensive studies are required to determine the differences in susceptibility to $H$. pylori infection.

\section{Authors' contributions}

Gönen S, Sarı S, Kandur Y, Dalgıç B and Söylemezoğlu O contributed to data analysis, interpretation of the results and drafted the manuscript. All authors have read and approved the article for publication.

Gönen S, Sarı S, Kandur Y, Dalgıç B, Söylemezoğlu O. Avaliação de antígeno leucocitário humano classe I e II em pacientes pediátricos com gastrite e úlcera duodenal ativas e Helicobacter pylori positivo. Arq Gastroenterol. 2017;54(4):297-9.

RESUMO - Contexto - Determinada como sendo a primeira bactéria cancerígena, o Helicobacter pylori (H. pylori) é um patógeno localizado no estômago em mais da metade da população mundial. Alguns estudos anteriores têm encontrado uma relação entre câncer gástrico e antígenos de histocompatibilidade de tecido dependendo das regiões. Objetivo - O presente estudo teve como objetivo determinar a distribuição em nosso centro do antígeno leucocitário humano (HLA) de classe I e antígenos classe II em pacientes pediátricos H. pylori-positivos com gastrite e úlcera duodenal ativas, excluindo casos de câncer. Métodos - O estudo incluiu 40 pacientes H. pylori-positivos diagnosticados com gastrite e úlcera duodenal ativas e 100 controles consistindo de candidatos doadores saudáveis. Foram estudadas nas amostras de DNA isoladas o antígeno leucocitário humano classe I e antígenos classe II, utilizando-se as cadeias de sequência específica de polimerase do oligonucleotideo. Resultados - A frequência do antígeno HLA - B * 51 foi significativamente maior no grupo de pacientes do que no grupo controle $(40 \%$ vs $17 \% ; P=0,003)$. Não houve diferença entre os dois grupos em termos das frequências dos antígenos HLA-A, HLA-DR, HLA-DQ e HLA-C. Conclusão - Determinou-se que o HLA - B * 51 desempenha um papel crítico na infecção pelo H. pylori.

DESCRITORES - Úlcera duodenal. Gastrite. Helicobacter pylori. Antígenos HLA. Criança.

\section{REFERENCES}

1. Hollenbach JA, Mack SJ, Thomson G, Gourraud PA. Analytical methods for disease association studies with immunogenetic data. Methods Mol Biol. 2012;882:245-66

2. Huang LM, Cheng Y, Yu DK, Zhai K, Tan W, Lin DX. Association between HLA-DQA1 gene copy number polymorphisms and susceptibility to gastric cancer. Zhonghua Zhong Liu Za Zhi. 2012;34:269-71.

3. Huang YK, Wen GS, Li HL, Hao P, Qi Q, Zhou LF. Possible association between HLA-DRB1 and DQB1 genes frequency and susceptibility or resistance to Helicobacter pylori infection in Kunming Yi ethnic group children. Zhonghua Er Ke Za Zhi. 2005;43:137-40.

4. Köksal AS, Onder FO, Torun S, Parlak E, Sayilir A, Tayfur O, et al. Twice a day quadruple therapy for the first-line treatment of Helicobacter pylori in an area with a high prevalence of background antibiotic resistance. Acta Gastroenterol Belg. 2013;76:34-7.

5. Lee HW, Hahm KB, Lee JS, Ju YS, Lee KM, Lee KW. Association of the human leukocyte antigen class II alleles with chronic atrophic gastritis and gastric carcinoma in Koreans. J Dig Dis. 2009;10:265-71.

6. Li Z, Chen D, Zhang C, Li Y, Cao B, Ning T, et al. HLA polymorphisms are associated with Helicobacter pylori infected gastric cancer in a high risk population, China. Immunogenetics. 2005;56:781-7.

7. Magnusson PKE, Enroth H, Eriksson I, Held M, Nyrén O, Engstrand L, et al. Gastric cancer and human leukocyte antigen: distinct DQ and DR alleles are associated with development of gastric cancer and infection by Helicobacter pylori. Cancer Res. 2001;61:2684-9.
8. Marshall BJ, Warren JR. Unidentified curved bacilli in the stomach of patients with gastritis and peptic ulceration. Lancet. 1984;1:1311-5.

9. Naik S. The human HLA system. J Indian Rheumatol Assoc. 2003;11:79-83.

10. Nizhevich AA, Shcherbakov PL, Akhmadeeva EN, Sataev VU, Elicheva ZM, Usmanova IZ, et al. Immune polymorphism analysis of HLA class II antigens in ulcer diseases associated with Helicobacter pylori in children. Eksp Klin Gastroenterol. 2010;(1):58-63.

11. Wang J, Zhang Q, Liu Y, Han J, Ma X, Luo Y, et al. Association between HLA-IIgene polymorphism and Helicobacter pylori infection in Asian and European population: A meta-analysis. Microb Pathog. 2015;82:15-26.

12. Watanabe Y, Aoyama N, Sakai T, Shirasaka D, Maekawa S, Kuroda K, et al. HLA-DQB1 locus and gastric cancer in Helicobacter pylori infection. J Gastroenterol Hepatol. 2006;21:420-4.

13. Wilson AG, Duff GW. Genetic traits in common diseases. BMJ. 1995;310:1482-3.

14. Wu MS, Hsieh RP, Huang SP, Chang YT, Lin MT, Chang MC, et al. Association of HLA-DQB $1 * 0301$ and HLA-DQB $1 * 0602$ with different subtypes of gastric cancer in Taiwan. Jpn J Cancer Res. 2002;93:404-10.

15. Zhao Y, Wang J, Tanaka T, Hosono A, Ando R, Soeripto S, et al. Association between HLA-DQ genotypes and haplotypes vs Helicobacter pylori infection in an Indonesian population. Asian Pac J Cancer Prev. 2012;13:1247-51. 